\title{
Sex matching and red cell safety
}

\author{
Thanh T. Nguyen, MD, and Brian S. Donahue, MD, PhD
}

\footnotetext{
From the Division of Pediatric Anesthesia, Department of Anesthesiology, Monroe Carell Jr Children's Hospital at Vanderbilt, Vanderbilt University, Nashville, Tenn.

Disclosures: Authors have nothing to disclose with regard to commercial support.

Received for publication March 21, 2016; accepted for publication March 24, 2016; available ahead of print April $27,2016$.

Address for reprints: Brian S. Donahue, MD, PhD, Division of Pediatric Anesthesia, Department of Anesthesiology, Monroe Carell Jr Children's Hospital at Vanderbilt, Vanderbilt University, 2200 Children's Way, Nashville, TN 37232 (E-mail: brian.donahue@vanderbilt.edu).

J Thorac Cardiovasc Surg 2016;152:233-4

0022-5223/\$36.00

Copyright (C 2016 by The American Association for Thoracic Surgery

http://dx.doi.org/10.1016/j.jtcvs.2016.03.054
}

Although transfusion can be lifesaving in severe acute blood loss, evidence of increased morbidity and mortality associated with transfusion continues to be reported. ${ }^{1-6}$ These findings have resulted in an array of practices to not only improve the safety of the blood supply ${ }^{7}$ but also rationally limit transfusion. Because limiting transfusion means limiting transfusion risk, clinicians have sought evidence supporting specific transfusion practices. Although initial studies on restrictive versus liberal transfusion practices supported a lowering of most transfusion thresholds, ${ }^{2,8}$ more recent studies do not support these findings. ${ }^{9-13}$ Despite the conflicting data, the search continues for the safest transfusion.

Although some transfusion risks are related to the recipient, or the circumstances surrounding the transfusion, some arise from the donor unit itself. The red cell storage defect, which affects cell deformability and oxygen delivery, accounts for increased morbidity and mortality associated with increased storage age of the donor unit. $^{14-17}$ Another example is the risk of transfusion-related acute lung injury associated with female donors, human leukocyte antigen class II antibody, and anti-human neutrophil antigen. ${ }^{18,19}$ In this month's issue of the Journal, Bjursten and colleagues ${ }^{20}$ report another donor unit risk factor: Sex mismatch between the donor and the recipient (Figure 1). By using retrospective data from more than 11,000 cardiac surgery patients undergoing on-pump coronary artery bypass, aortic valve replacement, or both, the authors observe an independent association between sex-mismatched red cell transfusion and mortality.

Like any retrospective study, the current study carries the limitation of possible confounding. It is almost axiomatic that patients receive transfusions for specific reasons, without which they would not receive them. Therefore, it is difficult to completely separate the morbidity associated with transfusion from the morbidity associated with its indications by using epidemiologic data. Statistical approaches such as regression and propensity matching can sort out some independent confounders, but only those that we are able to identify and measure. But because

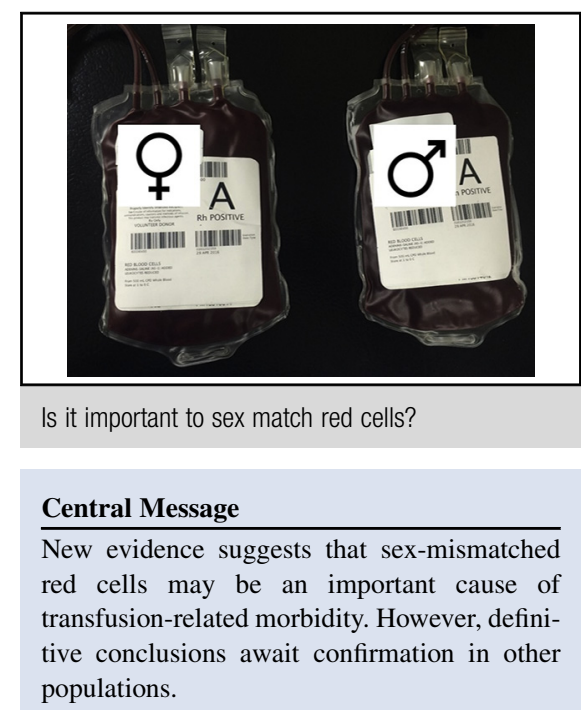

See Article page 223.

See Editorial page 18.

transfusion almost always occurs without regard (or even knowledge) of the donor's gender, the assignment of patients to gender-matched or mismatched groups is practically random, or at least haphazard and blinded. This advantage in study design lends support to the authors' conclusions.

Bjursten and colleagues $^{20}$ also report increased 1-year mortality associated with small transfusion (1-2 units) of

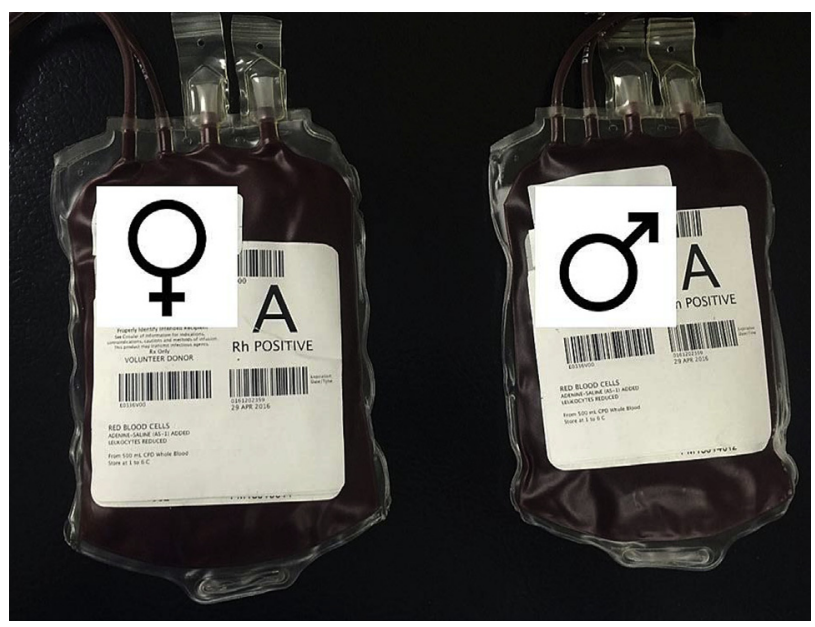

FIGURE 1. Is it important to sex match red cells? Epidemiologic evidence suggests a survival advantage. 
nonleukocyte-depleted red cells. Although the data on leukocyte-depleted transfusion are conflicting, ${ }^{21-24}$ the trajectory of red cell transfusion in the United States is trending toward complete leukocyte depletion of the red cell inventory. ${ }^{24,25}$ Of note, the authors did not observe increased mortality associated with age of the donor unit.

These results add to the limited data regarding sexmismatch transfusion. There is some evidence suggesting an association between sex-mismatch red blood cell units with mortality, ${ }^{26}$ but this observation is not universal. ${ }^{27}$ Reproducibility of these findings in other databases is a necessary first step for sex mismatch to become an established risk factor. A better mechanistic understanding of this risk is the next step. Both are probably needed before evidence-based practice recommendations can be made.

\section{References}

1. Holst LB. Benefits and harms of red blood cell transfusions in patients with septic shock in the intensive care unit. Dan Med J. 2016;63.

2. Koch CG, Li L, Duncan AI, Mihaljevic T, Cosgrove DM, Loop FD, et al. Morbidity and mortality risk associated with red blood cell and blood-component transfusion in isolated coronary artery bypass grafting. Crit Care Med. 2006;34:1608-16.

3. Koch CG, Li L, Van Wagoner DR, Duncan AI, Gillinov AM, Blackstone EH. Red cell transfusion is associated with an increased risk for postoperative atrial fibrillation. Ann Thorac Surg. 2006;82:1747-56.

4. Mariscalco G, Biancari F, Juvonen T, Zanobini M, Cottini M, Banach M, et al. Red blood cell transfusion is a determinant of neurological complications after cardiac surgery. Interact Cardiovasc Thorac Surg. 2015;20:166-71.

5. Silva Junior JM, Rezende E, Amendola CP, Tomita R, Torres D, Ferrari MT, et al. Red blood cell transfusions worsen the outcomes even in critically ill patients undergoing a restrictive transfusion strategy. Sao Paulo Med J. 2012;130:77-83.

6. Rawn J. The silent risks of blood transfusion. Curr Opin Anaesthesiol. 2008;21: 664-8.

7. Bolton-Maggs PH, Cohen H. Serious Hazards of Transfusion (SHOT) haemovigilance and progress is improving transfusion safety. Br J Haematol. 2013;163: 303-14.

8. Palmieri TL, Lee T, O'Mara MS, Greenhalgh DG. Effects of a restrictive blood transfusion policy on outcomes in children with burn injury. J Burn Care Res. 2007;28:65-70.

9. Murphy GJ, Pike K, Rogers CA, Wordsworth S, Stokes EA, Angelini GD, et al. Liberal or restrictive transfusion after cardiac surgery. N Engl J Med. 2015;372: 997-1008.

10. Patel NN, Avlonitis VS, Jones HE, Reeves BC, Sterne JA, Murphy GJ. Indications for red blood cell transfusion in cardiac surgery: a systematic review and meta-analysis. Lancet Haematol. 2015;2:e543-53.
11. Hebert PC, Wells G, Blajchman MA, Marshall J, Martin C, Pagliarello G, et al; Transfusion Requirements in Critical Care Investigators, Canadian Critical Care Trials Group. A multicenter, randomized, controlled clinical trial of transfusion requirements in critical care. $N$ Engl J Med. 1999;340:409-17.

12. McIntyre LA, Fergusson DA, Hutchison JS, Pagliarello G, Marshall JC, Yetisir E, et al. Effect of a liberal versus restrictive transfusion strategy on mortality in patients with moderate to severe head injury. Neurocrit Care. 2006:5:4-9.

13. Fominskiy E, Putzu A, Monaco F, Scandroglio AM, Karaskov A, Galas FR, et al. Liberal transfusion strategy improves survival in perioperative but not in critically ill patients. A meta-analysis of randomised trials. Br J Anaesth. 2015; 115:511-9.

14. Brunskill SJ, Wilkinson KL, Doree C, Trivella M, Stanworth S. Transfusion of fresher versus older red blood cells for all conditions. Cochrane Database Syst Rev. 2015;5:CD010801.

15. Kinnunen EM, Sabatelli L, Juvonen T, Biancari F. Red blood cell storage time and the outcome after coronary surgery. J Surg Res. 2015;197:58-64.

16. Marti-Carvajal AJ, Simancas-Racines D, Pena-Gonzalez BS. Prolonged storage of packed red blood cells for blood transfusion. Cochrane Database Syst Rev. 2015;7:CD009330.

17. Patterson JA, Irving DO, Isbister JP, Morris JM, Mayson E, Roberts CL, et al. Age of blood and adverse outcomes in a maternity population. Transfusion. 2015;55: 2730-7.

18. Schmickl CN, Mastrobuoni S, Filippidis FT, Shah S, Radic J, Murad MH, et al. Male-predominant plasma transfusion strategy for preventing transfusion-related acute lung injury: a systematic review. Crit Care Med. 2015;43:205-25.

19. Toy P, Gajic O, Bacchetti P, Looney MR, Gropper MA, Hubmayr R, et al. Transfusion-related acute lung injury: incidence and risk factors. Blood. 2012; 119:1757-67.

20. Bjursten H, Dardashti A, Björk J, Wierup P, Algotsson L, Ederoth P. Transfusion of sex-mismatched and non-leukocyte-depleted red blood cells in cardiac surgery increases mortality. J Thorac Cardiovasc Surg. 2016;152:223-32.e1.

21. Bilgin YM, van de Watering LM, Eijsman L, Versteegh MI, Brand R, van Oers $\mathrm{MH}$, et al. Double-blind, randomized controlled trial on the effect of leukocyte-depleted erythrocyte transfusions in cardiac valve surgery. Circulation. 2004;109:2755-60.

22. Bolcal C, Akay HT, Bingol H, Doganci S, Yildirim V, Yenicesu M, et al. Leukodepletion improves renal function in patients with renal dysfunction undergoing on-pump coronary bypass surgery: a prospective randomized study. Thorac Cardiovasc Surg. 2007; 55:89-93.

23. Efstathiou A, Vlachveis M, Tsonis G, Asteri T, Psarakis A, Fessatidis IT. Does leukodepletion during elective cardiac surgery really influence the overall clinical outcome? J Cardiovasc Surg (Torino). 2003;44:197-204.

24. Vamvakas EC, Blajchman MA. Blood still kills: six strategies to further reduce allogeneic blood transfusion-related mortality. Transfus Med Rev. 2010;24:77-124.

25. Spinella PC, Dressler A, Tucci M, Carroll CL, Rosen RS, Hume H, et al. Survey of transfusion policies at US and Canadian children's hospitals in 2008 and 2009. Transfusion. 2010;50:2328-35.

26. Desmarets M, Bardiaux L, Benzenine E, Dussaucy A, Binda D, Tiberghien P, et al. Effect of storage time and donor sex of transfused red blood cells on 1-year survival in patients undergoing cardiac surgery: an observational study. Transfusion. March 2, 2016 [Epub ahead of print].

27. Middelburg RA, Briet E, van der Bom JG. Mortality after transfusions, relation to donor sex. Vox Sang. 2011;101:221-9. 